\title{
Chirurgická léčba symptomatické hypertrofické obstrukční kardiomyopatie
}

\author{
Jan Vojáček, Pavel Nedbal*, Jan Dominik, Martin Tuna, Pavel Žáček, Miroslav Brtko, Jan Harrer \\ Kardiochirurgická klinika, Fakultní nemocnice Hradec Králové, Univerzita Karlova v Praze a Lékařská fakulta v Hradci Králové, \\ Hradec Králové, *Kardiocentrum nemocnice Liberec, Liberec, Česká republika
}

Mezi nejčastější způsoby nemedikamentózní léčby symptomatické dynamické obstrukce výtokového traktu levé komory (LVOT) u pacientů s hypertrofickou obstrukční kardiomyopatií (HOCM) patří chirurgická myektomie nebo alkoholová septální ablace. Výsledky chirurgické léčby jsou v centrech, kde s touto operací mají dostatek zkušeností, výborné. Mortalita je v těchto souborech velmi nízká a přežívání pacientů je po operaci obdobné jako u normální zdravé populace. ${ }^{(1)}$

Principem myektomie je rozsáhlá resekce svaloviny hypertrofického septa komor, zejména v oblasti výtokového traktu levé komory, ale i ve střední části mezikomorové přepážky. Je-li myektomie správně provedena, vede ve velké většině př́ípadů $\mathrm{k}$ uvolnění dynamické obstrukce LVOT, vymizení nebo alespoň významnému zmenšení SAM (systolic anterior motion) předního cípu mitrální chlopně a k významné redukci nitrokomorového gradientu.

Popis kasuistiky: Padesátiletý pacient se symptomatickou HOCM, závažnou dynamickou obstrukcí LVOT, spojenou se SAM předního cípu mitrální chlopně, a s významnou stenózou na dvojcípé aortální chlopni, byl indikován
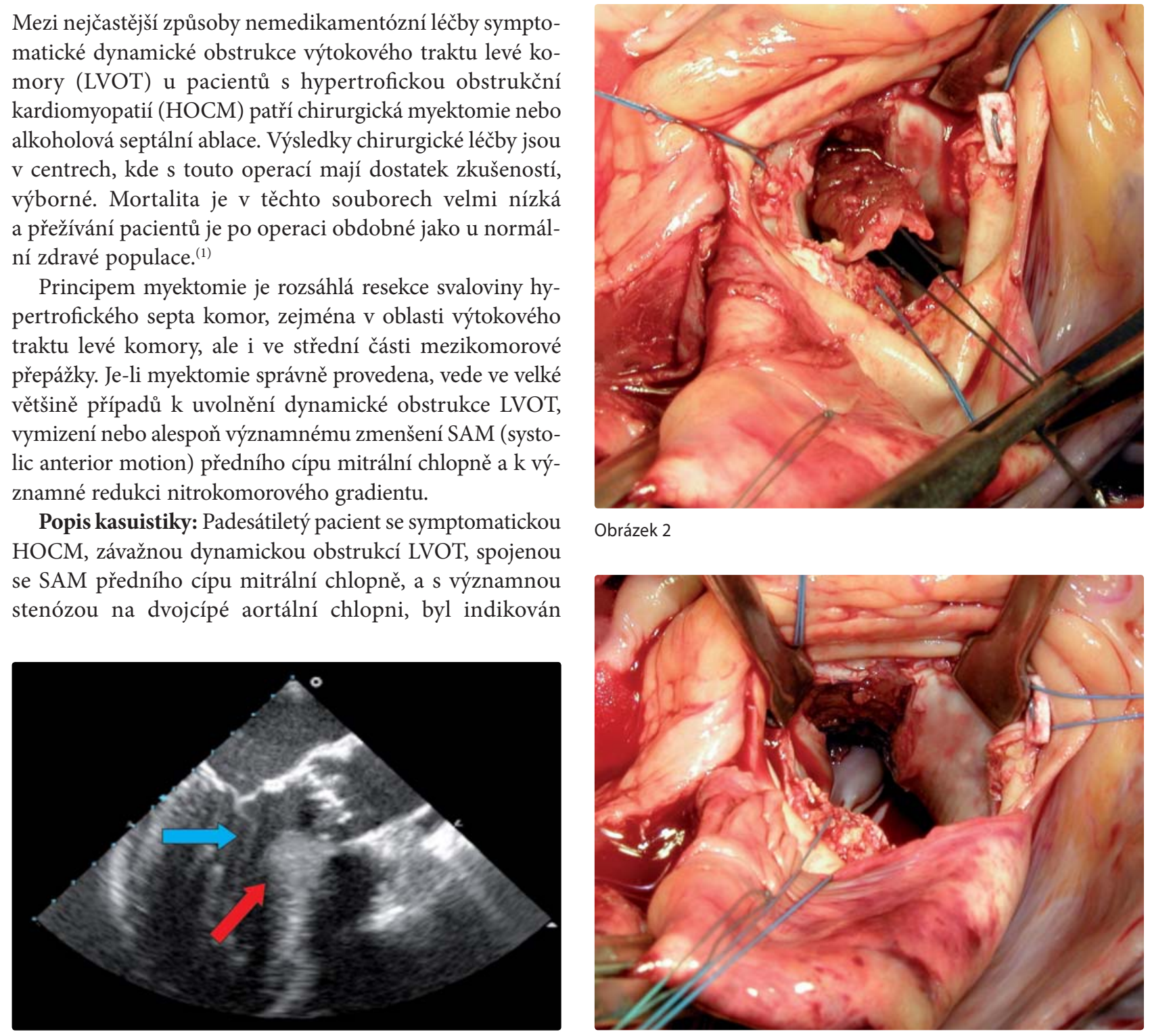

Obrázek 2

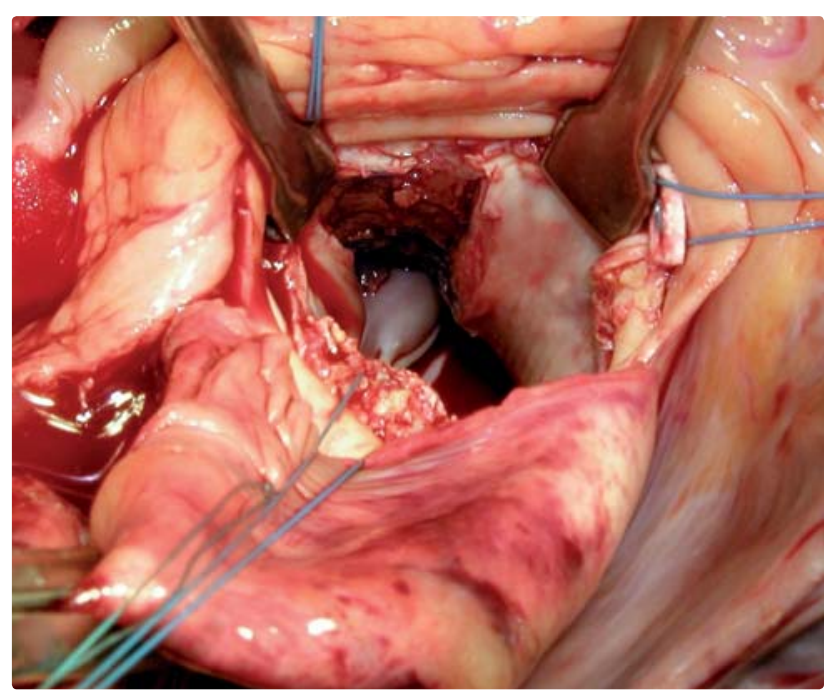

Obrázek 1

Obrázek 3

Adresa: doc. MUDr. Jan Vojáček, Ph.D., Kardiochirurgická klinika, Fakultní nemocnice Hradec Králové, Sokolská 581, 50005 Hradec Králové, Česká republika, e-mail: vojacek.jan@fnhk.cz 


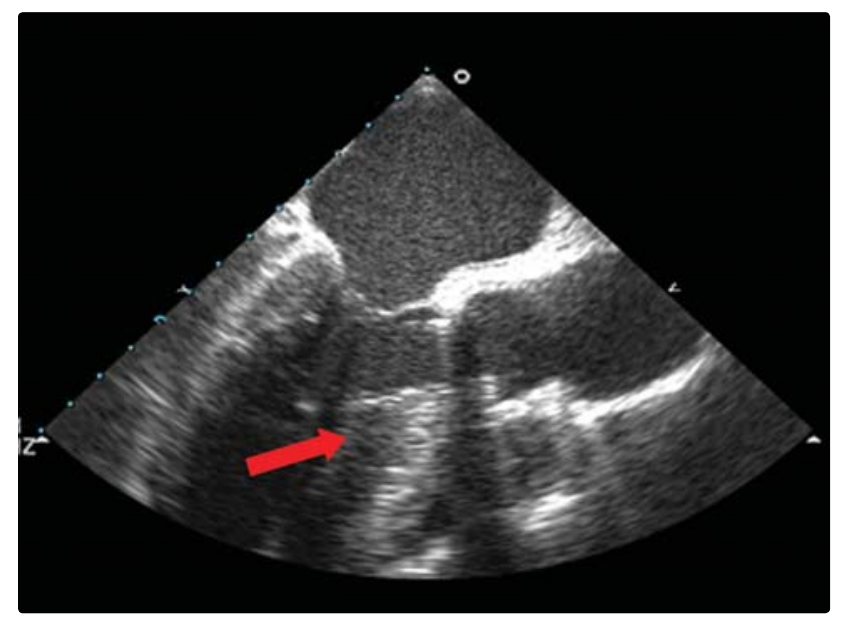

Obrázek 4

k náhradě aortální chlopně a chirurgické myektomii septa komor. Na předoperační echokardiografii (obrázek 1) je patrný SAM (modrá šipka) a významná hypertrofie septa (červená šipka). Během operace byla nejprve z prríčné aortotomie provedena excize stenotické bikuspidální aortální chlopně. Po ní následovala vlastní septální myektomie podle
Morrowa. Při ní se ze septa komor v oblasti LVOT a střední části septa vytíná bloček svaloviny hloubky až $10 \mathrm{~mm}$ (obrázek 2). Myektomii je nutno provést v maximálním možném rozsahu, aby bylo dosaženo vymizení obstrukce. Na druhou stranu je nutná opatrnost, aby nedošlo k perforaci mezikomorové přepážky (nutno znát rozměr a morfologii septa) nebo $k$ poranění převodního systému s následným vznikem atrioventrikulárního bloku III. stupně (incize nesmí být vedena více vpravo, než odpovídá středu pravého koronárního cípu). Myektomie začíná pod úponem aortální chlopně a končí až u báze papilárních svalů (obrázek 3). Po provedení myektomie byla aortální chlopeň nahrazena mechanickou protézou. Pooperační echokardiografie prokázala dobrý účinek myektomie s vymizením obstrukce LVOT a SAM předního cípu mitrální chlopně (obrázek 4, červená šipka).

\section{Literatura}

1. Smedira NG, Lytle BW, Lever HM, et al. Current effectiveness and risk of isolated septal myectomy for hypertrophic obstructive cardiomyopathy. Ann Thorac Surg 2008;85:127-33. 